\title{
Amino Acids
}

National Human Genome Research Institute (NHGRI)

\section{Source}

National Human Genome Research Institute (NHGRI). Amino Acids.

Amino acids are a set of 20 different molecules used to build proteins. Proteins consist of one or more chains of amino acids called polypeptides. The sequence of the amino acid chain causes the polypeptide to fold into a shape that is biologically active. The amino acid sequences of proteins are encoded in the genes.

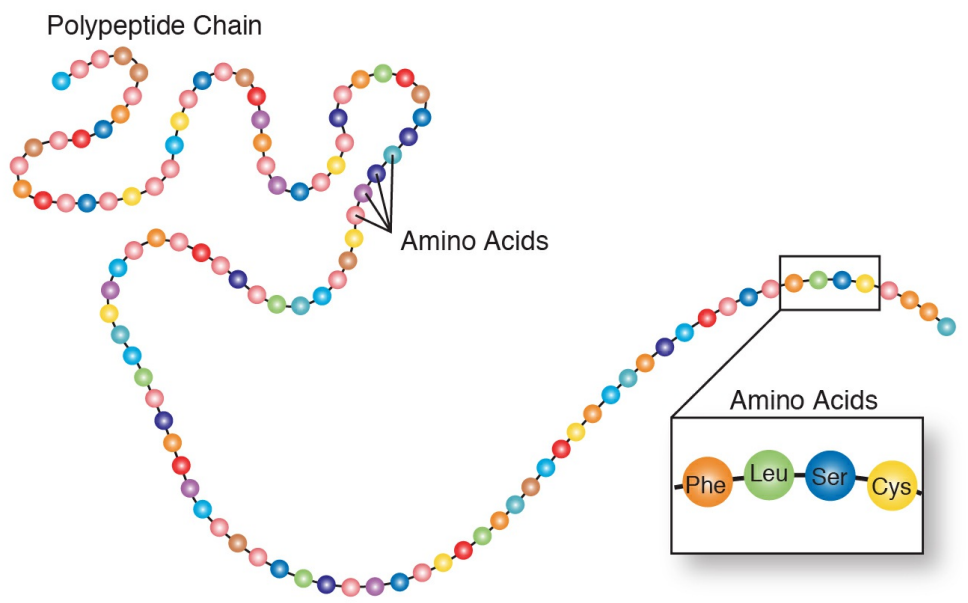

Amino Acids

$\begin{array}{llll}\text { Ala: Alanine } & \text { Gln: Glutamine } & \text { Leu: Leucine } & \text { Ser: Serine } \\ \text { Arg: Arginine } & \text { Glu: Glutamic acid } & \text { Lys: Lysine } & \text { Thr: Threonine } \\ \text { Asn: Asparagine } & \text { Gly: Glycine } & \text { Met: Methionine } & \text { Trp: Tryptophane } \\ \text { Asp:Aspartic acid } & \text { His: Histidine } & \text { Phe: Phenylalanine } & \text { Tyr: Tyrosisne } \\ \text { Cys:Cysteine } & \text { lle: Isoleucine } & \text { Pro: Proline } & \text { Val: Valine }\end{array}$

Figure 